УДК 378.046 .4

\title{
ПРОГРАМА НАВЧАЛЬНОЇ ДИСЦИПЛІНИ “АНГЛІЙСЬКА МОВА ДЛЯ ПЕРЕКЛАДАЧІВ”
}

\author{
Голуб Д. О., Коробейнікова Т. І., Миронова Т.Ю. \\ darja.golub@gmail.com, tikorobeinikova@gmail.com,myronova77@gmail.com \\ Університет іменіАльфреда Нобеля, Дніпро \\ Дата надходження 11.03.2019. Рекомендовано до друку 20.05.2019.
}

\begin{abstract}
Анотація. Програму призначено для здобувачів першого року навчання бакалаврського рівня вищої освіти зі спеціальності 035 Філологія “Переклад (англійська)”. Мета навчальної дисципліни - формування англомовної комунікативної компетентності здобувачів-філологів на рівні В2+ та початкових навичок і вмінь перекладу з англійської мови на українську та з української на англійську мову в межах знайомих лексичних одиниць і граматичних структур, необхідних для подальшого професійного розвитку. Програма містить чотири модулі, які побудовані з урахуванням мовних аспектів і видів мовленнєвої діяльності в межах тем повсякденного спілкування. Програма визначає зміст навчальної дисципліни, заплановані результати навчання; орієнтовний перелік питань підсумкового контролю; порядок оцінювання результатів навчання, список рекомендованої літератури (основної та допоміжної), а також інформаційні ресурси інтернет за темами навчального курсу.

Ключові слова: галузь знань 03 Гуманітарні науки, спеціальність 035 Філологія, бакалаврський рівень, англійська мова, перекладач, перший курс.
\end{abstract}

Голубь Д. А., Коробейникова Т. И., Миронова Т. Ю. Университет имени Альфреда Нобеля, Днепр Программа учебной дисциплины “Английский язык для переводчиков”

Аннотация. Программа предназначена для первого курса обучения соискателей степени “бакалавр” специальности 035 Филология “Перевод (английский язык)”. Цель учебной дисциплины - формирование англоязычной коммуникативной компетентности соискателей-филологов на уровне В2 + и начальных навыков перевода с английского языка на украинский и с украинского на английский язык в рамках знакомых лексических единиц и грамматических структур, необходимых для подготовки к будущей профессиональной деятельности. Программа содержит четыре модуля, построенные с учётом языковых аспектов языка и видов речевой деятельности по темам повседневного общения. В программе предложены содержание обучения, запланированные результаты, ориентировочный список вопросов итогового контроля, порядок оценивания результатов обучения, список рекомендуемой литературы (основной и дополнительной), а также информационные ресурсы интернета по темам учебного курса.

Ключевые слова: гуманитарные науки, специальность 035 Филология, бакалаврский уровень, английский язык, переводчик, первый курс.

Holub D., Korobeinikova T., Myronova T. Alfred Nobel University, Dnipro

The Curriculum of the Course "English Language for Translators".

Abstract. The curriculum of the course is designed for the first-year students majoring in 03 Humanitarian Sciences, specialism 035 Philology "Translation (English language)" and studying General English at CEF level B2+. It is aimed at developing B2+ students' English competence as well as in the basic translation from English into Ukrainian, and from Ukrainian into English using common lexical units and grammar patterns. This allows students to be properly prepared for effective communication in their academic and professional environments. The course covers four themed modules with a variety of everyday topics which provide practice in all language skills. The curriculum of the course also contains interactive exercises and gamification elements presented on the international innovative Digital Platform Digibooks Express Publishing, which motivates students to enhance their language skills. The curriculum determines the content of the course, learning outcomes, list of the issues for the final test, the procedure of assessing learning outcomes. It is suggested the list of the main and additional references as well as the Internet resources on the topics of the course.

Key words: Humanitarian Sciences, specialism 035 Philology, Bachelor of Arts, English, translator, first year of study. 
Програму обов'язкової навчальної дисципліни “Англійська мова для перекладачів” укладено відповідно до освітньо-професійної програми “Переклад (англійська мова)" для першого (бакалаврського) рівня вищої освіти й навчального плану для першого року навчання за спеціальністю 035 Філологія. Дисципліна забезпечує особистісний і професійний розвиток здобувачів. Метою програми є формування англомовної комунікативної компетентності студентівфілологів на рівні В2+, що передбачає спрямування на формування початкових навичок і вмінь перекладу з англійської мови на українську та з української на англійську мову в межах знайомих лексичних одиниць і граматичних структур, необхідних для подальшого професійного розвитку.

На вивчення дисципліни припадає 22 кредити, що складає 660 навчальних годин, 3 яких 200 годин - аудиторна робота та 460 годин - самостійна й індивідуальна робота студента.

Зміст дисципліни й вибір методів іiї викладання спрямовані на оволодіння основними видами іншомовної мовленнєвої діяльності: аудіюванням, читанням, письмом, говорінням у діалогічній і монологічній формах. Одним із фокусів програми $€$ вдосконалення у здобувачів англомовної фонетичної компетентності, а саме коригування вимови звуків й інтонації з орієнтацією на британський стандарт мовлення. Самостійна робота здобувачів вибудувана на основі використання інноваційної міжнародної Інтернет платформи DigiBooks Express Publishing, що сприяє глибшому засвоєнню пройденого під час аудиторних занять матеріалу завдяки інтерактивним вправам і мотивуючому елементу гейміфікації.

\section{1. Програма навчальної дисципліни}

Програма дисципліни складається із чотирьох змістових модулів: Змістовий модуль 1 "Робота"; Змістовий модуль 2 - "Подорожі. Покупки"; Змістовий модуль 3 - “Світ навколо"; Змістовий модуль 4 - "Мистецтво: кіно, театр, телебачення".

Тематична матриця дисципліни “Англійська мова для перекладачів”

\begin{tabular}{|c|c|c|c|}
\hline Тема & Фонетика & Граматика & Лексика \\
\hline Робота & $\begin{array}{l}\text { приголосні, } \\
\text { наголос }\end{array}$ & $\begin{array}{l}\text { теперішній час, } \\
\text { майбутній час, } \\
\text { синтаксис речення } \\
\text { (підмет і присудок: } \\
\text { типи, форми) }\end{array}$ & $\begin{array}{l}\text { можливості трудової діяльності } \\
\text { (способи заробітку, робота та гроші, } \\
\text { стиль життя, особистісні якості } \\
\text { та характеристики) }\end{array}$ \\
\hline $\begin{array}{l}\text { Подорожі. } \\
\text { Покупки }\end{array}$ & $\begin{array}{l}\text { голосні, } \\
\text { наголос у } \\
\text { багатоскладови } \\
\text { х словах }\end{array}$ & $\begin{array}{l}\text { минулий час, артиклі, } \\
\text { прикметники, } \\
\text { прислівники, } \\
\text { другорядні члени } \\
\text { речення }\end{array}$ & $\begin{array}{l}\text { подорожі (витрати на подорож, } \\
\text { відвідування різних місць, } \\
\text { знаходження правильного шляху, } \\
\text { проблеми під час подорожі) } \\
\text { покупки (досвід покупок, он-лайн } \\
\text { покупки) }\end{array}$ \\
\hline $\begin{array}{l}\text { Світ } \\
\text { навколо }\end{array}$ & $\begin{array}{l}\text { голосні } \\
\text { інтонація } \\
\text { розповідного } \\
\text { речення }\end{array}$ & $\begin{array}{l}\text { непряма мова, } \\
\text { модальні дієслова } \\
\text { (can, may, must, to be } \\
\text { to, to have to) }\end{array}$ & $\begin{array}{l}\text { навколишне середовище; стихійні } \\
\text { лиха; природа (проблеми } \\
\text { навколишнього середовища } \\
\text { і соціальні питання, стихійні лиха) }\end{array}$ \\
\hline $\begin{array}{l}\text { Мистецтво. } \\
\text { Кіно, } \\
\text { театр, } \\
\text { телебачення }\end{array}$ & $\begin{array}{l}\text { дифтонги } \\
\text { інтонація } \\
\text { запитань }\end{array}$ & $\begin{array}{l}\text { модальні дієслова } \\
\text { (shall, will, should, } \\
\text { would, ought to, need, } \\
\text { dare), пасивний стан, } \\
\text { умовний спосіб }\end{array}$ & $\begin{array}{l}\text { настрій, стрес, почуття й емоцї̈ } \\
\text { (мова тіла, етапи життя, почуття } \\
\text { та емоції, хобі) } \\
\text { теле, радіо, кіно, мистецтво }\end{array}$ \\
\hline
\end{tabular}


Голуб Д. О., Коробейнікова Т. І., Миронова Т. Ю. Програма навчальної дисципліни “Англійська мова для перекладачів”

Тематична матриця дисципліни “Англійська мова для перекладачів”(продовження)

\begin{tabular}{|c|c|c|c|c|}
\hline Тема & Аудіювання & Читання & Говоріння & Письмо \\
\hline Робота & $\begin{array}{l}\text { Оголошення } \\
\text { Співбесіда }\end{array}$ & $\begin{array}{l}\text { Тексти-оголошення, } \\
\text { Тексти-рекомендації } \\
\text { щодо особливостей } \\
\text { співбесіди, порівняння. } \\
\text { Домашнє читання }\end{array}$ & $\begin{array}{l}\text { Співбесіда на роботу. } \\
\text { Стиль життя, } \\
\text { особистісні якості, } \\
\text { вибір роботи }\end{array}$ & $\begin{array}{l}\text { Лист-заявка на } \\
\text { працевлаштув } \\
\text { ання (ділове } \\
\text { листування) } \\
\text { Резюме }\end{array}$ \\
\hline $\begin{array}{l}\text { Подорожі. } \\
\text { Покупки }\end{array}$ & $\begin{array}{l}\text { Радіо } \\
\text { інтерв’ю, } \\
\text { Монологи }\end{array}$ & $\begin{array}{l}\text { Тексти-описи } \\
\text { визначних місць, } \\
\text { вражень, різних речей, } \\
\text { товарів, послуг } \\
\text { Домашнє читання }\end{array}$ & $\begin{array}{l}\text { Вираження вибору / } \\
\text { причини / пріоритету. } \\
\text { Надання рекомендацій } \\
\text { щодо вибору товарів, } \\
\text { послуг }\end{array}$ & $\begin{array}{l}\text { Історія } \\
\text { Описи товарів, } \\
\text { послуг } \\
\text { Рекомендації } \\
\text { туристу } \\
\end{array}$ \\
\hline Світ навколо & $\begin{array}{l}\text { Лекція } \\
\text { Телевізійне } \\
\text { інтерв’ю }\end{array}$ & $\begin{array}{l}\text { Статті про проблеми } \\
\text { навколишнього } \\
\text { середовища. } \\
\text { Домашнє читання }\end{array}$ & $\begin{array}{l}\text { Діалог-обговорення } \\
\text { проблем } \\
\text { навколишнього } \\
\text { середовища. } \\
\text { Монолог-міркування }\end{array}$ & $\begin{array}{l}\text { Есе (вирішення } \\
\text { проблем) } \\
\text { Письмова } \\
\text { доповідь } \\
\text { Опис }\end{array}$ \\
\hline $\begin{array}{l}\text { Мистецтво. } \\
\text { Кіно, театр, } \\
\text { телебачення }\end{array}$ & $\begin{array}{l}\text { Інтерв’ю } \\
\text { Уривок } \\
\text { фільму }\end{array}$ & $\begin{array}{l}\text { Текст-роздум щодо } \\
\text { стресу, життя зірок. } \\
\text { видатних людей. } \\
\text { Резюме книги, фільму } \\
\text { Домашнє читання }\end{array}$ & $\begin{array}{l}\text { Діалог-розпитування. } \\
\text { Діалог-обмін- } \\
\text { враженнями, } \\
\text { думками } \\
\text { Монолог-оповідь }\end{array}$ & $\begin{array}{l}\text { Eсе (власна } \\
\text { думка) } \\
\text { Огляд фільмів }\end{array}$ \\
\hline
\end{tabular}

\section{2. Заплановані результати навчання}

Після опанування курсу здобувач:

- збагачує свій словниковий запас новими лексичними одиницями в межах тем курсу та демонструє володіння англійською мовою на рівні В2+ в читанні текстів, які містять головним чином найуживаніші повсякденні мовленнєві зразки;

- володіє англійською мовою на рівні В2+ в діалогічному та монологічному мовленні на знайомі теми (сім'я, хобі, робота, подорожі та поточні події / новини);

- уміє вільно оперувати релевантною лексикою у спілкуванні з носіями мови з таким ступенем швидкості та спонтанності, який не завдає труднощів жодній із сторін;

- у спілкуванні на широке коло тем здатен висловлювати свою думку з певної проблеми, надаючи відповідні обгрунтовані аргументи за і проти, при цьому використовує широкий діапазон словникового запасу;

- у розповіді, історії або переказі сюжетів книжки чи фільму описує своє ставлення, вдаючись до мовленнєвих засобів вираження емоцій;

- володіє навичками письма на рівні В2+ в межах тем, пов'язаних з особистими інтересами;

• узагальнює, конкретизує й аргументує інформацію або певну точку зору під час написання есе, доповіді тощо;

- під час написання листів наголошує на особистому значенні минулих і теперішніх подій;

- сприймає на слух різножанрові автентичні тексти рівня В2+, а саме: великообсягові висловлювання, лекції, телевізійні програми та новини про поточні події, уривки фільмів літературною англійською мовою;

- використовує широкий спектр граматичних конструкцій у мовленнєвій діяльності в різноманітних ситуаціях спілкування для розв'язання проблем чи завдань;

- володіє базовими поняттями та загальними положеннями фонетики британського варіанта англійської мови, застосовує набуті знання, навички й уміння під час монологічного та діалогічного мовлення; 
- використовує сучасні інформаційні технології та одно/двомовні словники для виконання самостійної й індивідуальної роботи для пошуку загальної інформації під час підготовки усної доповіді чи презентації;

• володіє початковими навичками та вміннями перекладу з англійської мови на українську та з української на англійську мову в межах знайомих лексичних одиниць та граматичних структур.

\section{3. Орієнтовний перелік питань підсумкового контролю}

1. Робота та співбесіда.

2. Стиль життя.

3. Особистісні якості людей.

4. Подорожі: нові відкриття та досвід.

5. Світ покупок: в магазині чи через Інтернет.

6. Проблеми навколишнього середовища.

7. Стихійні лиха та катастрофи.

8. Соціальні проблеми: булінг, нерівність, дискримінація.

9. Почуття та емоції.

10. Стрес і шляхи подолання негативних наслідків.

11. Світ театру та кіно.

12. Види мистецтв.

13. Теперішній, минулий та майбутній часи.

14. Непряма мова.

15. Модальні дієслова.

16. Пасивний стан.

17. Умовний спосіб.

18. Підготування доповіді/презентації за пройденою тематикою.

19. Опис, порівняння та протиставлення зображень.

20. Стислий огляд тексту за пройденою тематикою.

\section{4. Порядок оцінювання результатів навчання}

Підсумкова оцінка 3 дисципліни виставляється за 100-бальною шкалою. Завданнями поточного модульного контролю знань здобувачів $€$ перевірка та оцінка: а) систематичності й активності роботи здобувача на аудиторних заняттях; б) виконання завдань, виданих для самостійного опрацювання; в) виконання модульних контрольних завдань; г) розуміння та засвоєння матеріалу, набутих навичок і вмінь самостійного опрацювання матеріалу, тобто здатності самостійно працювати з літературою й іншими джерелами, аналізувати й узагальнювати зміст теми, а також умінь усно чи письмово подавати матеріал у вигляді презентації, відповідей на запитання тощо.

Результати поточного контролю знань здобувачів вищої освіти входять як складові елементи до загальної оцінки знань здобувачів за семестр. Студент допускається до заліку або екзамену, якщо за результатами роботи протягом семестру він отримав не менше 36-ти балів. Якщо отримано менше 36-ти балів, без доопрацювання визначених викладачем завдань студент не допускається до підсумкового контролю. Максимальний бал за результатами поточного контролю та модульної роботи студента вираховується в межах 60 балів. Результати екзамену оцінюються в діапазоні від 0 до 40 балів (включно). Екзамен проводиться у вигляді підсумкової письмової роботи та іiі усної складової, що містить комунікативні завдання в продукуванні діалогів і монологів. Якщо студент за результатами підсумкового контролю набрав менше 24-х балів, він отримує незадовільну оцінку, незалежно від результатів за семестр. 
Розподіл балів за змістовими модулями-темами та формами діагностики

\begin{tabular}{|c|c|}
\hline Форми діагностики & $\begin{array}{l}\text { Максимальна } \\
\text { кількість балів }\end{array}$ \\
\hline \multicolumn{2}{|l|}{ Змістовий модуль 1 - 2} \\
\hline $\begin{array}{l}\text { Індивідуальне опитування; фронтальне опитування; поточні } \\
\text { письмові роботи; тестування; робота в групах/парах; рольові } \\
\text { ігри; презентація-доповідь } 3 \text { домашнього читання }\end{array}$ & 50 \\
\hline Модульна контрольна робота №1 & 25 \\
\hline Модульна контрольна робота №2 & 25 \\
\hline Усього за перший семестр (залік) & 100 \\
\hline \multicolumn{2}{|l|}{ Змістовий модуль 3 - 4} \\
\hline $\begin{array}{l}\text { Індивідуальне опитування; фронтальне опитування; поточні } \\
\text { письмові роботи; тестування; робота в групах/парах; рольові } \\
\text { ігри; презентація-доповідь } 3 \text { домашнього читання }\end{array}$ & 30 \\
\hline Модульна контрольна робота №3 & 15 \\
\hline Модульна контрольна робота №4 & 15 \\
\hline Екзамен & 40 \\
\hline Усього за другий семестр & 100 \\
\hline
\end{tabular}

Шкала оцінювання

\begin{tabular}{|c|c|c|}
\hline $\begin{array}{c}\text { Оцінка за } \\
\text { шкалою ЕСТS }\end{array}$ & $\begin{array}{l}\text { Шкала } \\
\text { рейтингу }\end{array}$ & $\begin{array}{l}\text { Оцінка за національною } \\
\text { (чотирибальною) шкалою }\end{array}$ \\
\hline $\mathrm{A}$ & $90-100$ & 5 (відмінно) \\
\hline B & $82-89$ & 4 (дуже добре) \\
\hline $\mathrm{C}$ & $75-81$ & 4 (добре) \\
\hline $\mathrm{D}$ & $67-74$ & 3 (задовільно) \\
\hline $\mathrm{E}$ & $60-66$ & 3 (достатньо) \\
\hline FX & $35-59$ & $\begin{array}{c}2 \text { (незадовільно) - потрібно допрацювати } \\
\text { матеріал перед тим, як складати }\end{array}$ \\
\hline $\mathrm{F}$ & $1-34$ & $\begin{array}{c}2 \text { (незадовільно) - } 3 \text { обов’язковим повторним } \\
\text { вивченням дисципліни }\end{array}$ \\
\hline
\end{tabular}

\section{Рекомендована література}

Основна

1. Зінукова Н.В. Практична граматика англійської мови = Practical English Grammar. Ч. I: навчальний посібник / Н.В. Зінукова, І.В. Іщенко, М.С. Бірюкова. - Дніпропетровськ: Вид-во ДУЕП, 2011. - 252c. 
2. МироноваТ.Ю., Голуб Д.О. Практикум з фонетики англійської мови. Приголосні. Ч. І) [Електронний ресурс] / за ред. Н.В. Зінукової - Дніпро: Університет імені Альфреда Нобеля, 2019. $-91 \mathrm{c}$.

3.Evans V. On Screen B2 + :Student'sBook / V. Evans, J. Dooley. - Newbury: Express Publishing, 2014. - $192 \mathrm{p}$.

4. Evans V. On Screen B2+ : Workbook and Grammar Book / V. Evans, J. Dooley. - Newbury: Express Publishing, 2014. - $184 \mathrm{p}$.

5. Evans V. On Screen B2+ : Writing Book / V. Evans, J. Dooley. - Newbury: Express Publishing, 2014. $-31 \mathrm{p}$

6. Evans V. On Screen B2 + : Teacher's Book / V. Evans, J. Dooley. - Newbury: Express Publishing, 2014. $-350 \mathrm{p}$.

\section{Допоміжна}

1. Английский язык: Учеб.для І курса филол. ф-тов / Т. И. Матюшкина-Герке, С. П. Балашова, Н. Н. Проссе и др. - М., 2004. - 527 с.

2. Винарева Л. А. Английские идиомы / Л. А. Винарева, В. В. Янсон. - К., 2005. - 384 с.

3. Возна М. О. Англійська мова для перекладачів і філологів. І курс: Підручник / М. О. Возна, А. Б. Гапонів, О. О. Акулова, Н. С. Хоменко, В. С. Гуль. - Вінниця, 2004. - 480 с.

4. Войтенок В. М. Разговорный английский язык / В. М. Войтенок, А. М. Войтенко. - М., 2001. $-474 \mathrm{c}$.

5. Гужва Т. Английский язык / Т. Гужва. - К., 1995. - 352 с.

6. Живой английский. Беседы носителей языка (Великобритания) по 19 темам / Под.ред. А. И. Пахотина. - К., 2004. - 264 с.

7. Карабан В. І. Практична граматика англійської мови з вправами / В. I. Карабан, Л. М. Черноватий. - Вінниця, 2005. - 288 с.

8. Каушанская В. Л. Грамматика английского языка. Синтаксис / В. Л. Каушанская. - К., 1997. $-100 \mathrm{c}$.

9. Каушанская В. Л. Грамматика английского языка. Морфология / В. Л. Каушанская. - К., 1997. $-214 \mathrm{c}$.

10. Каушанская В. Л. Сборник упражнений по грамматике английского языка / В. Л. Каушанская. - Л., 1996. - 214 с.

11. Левашова В. А. Britain Today: Life and Institutions / В. А. Левашова. - М., 2001. - 216 c.

12. Матукайтес 3. В. Разговорный английский язык / 3. В. Матукайтес, А. И. Денисова и др. - М., 1969. - 328 с.

13. Меркулова Е. М. Английский язык. Чтение, письменная и устная практика / Е. М. Меркулова. - СПб., 2004. - 368 с.

14. Практический курс английского языка. 2 курс / Под ред. В. Д. Аракина. - М., 1998. $515 \mathrm{c}$.

15. Стабурова Л. Г. Английский язык / Л. Г. Стабурова, Б. А. Дианова и др. - Л., 1976. $454 \mathrm{c}$.

16. Черноватий Л. М. Практичний курс англійської мови. Ч. 1 / Л. М. Черноватий, В. І. Карабан. - Вінниця, 2005. - 432 с.

17.Янсон В. Практичний курс англійської мови для студентів вищих навчальних закладів. Кн. ІІ. / В. Янсон, Л. Свистун. - К., 2002. -368 с.

18. Azar B. Sh. Understanding and Using English Grammar / B. Sh. Azar. - New York, 1999. $437 \mathrm{p}$.

19. Gordon E. M. A Grammar of Present-Day English / E. M. Gordon, I. P. Krylova. - M., 1980. $432 \mathrm{p}$. 
20. Kobrina N. A. An English Grammar.Morphology / N. A. Kobrina, E. A. Korneyeva. - M., 1985. $-288 \mathrm{p}$.

21. Murphy R. English Grammar in Use / R. Murphy. - Cambridge, 1994. - 350 p.

22. Граматика англійської мови / Ольга Коваленко, Тетяна Коробейнікова, Ольга Кузнєцова. К. : Арій, 2017. - 112 с.

\section{Домашне читання}

1. The Picture of Dorian Gray / Оскар Уальд; адапт., вправи, словник T.I. Коробейнікової, Г. Г. Прохоренка. - К. : Арій, 2015. (Читаю англійською). - 160 с.

2. The Man with the Scar and otherstories / Сомерсет Моем; адапт., вправи, словник О. А. Борити, T. І. Коробейнікової. - К. : Арій, 2015. (Читаю англійською). - 160 с.

3. Stories / Едгар Аллан По: адап., вправи, словник T.I. Коробейнікової. - К. : Арій, 2017. - 160 с. (Читаю англійською (Upper-Intermediate Level))

4. The adventures of Oliver Twist / Чарльз Діккенс: уклад., вправи, словник T.I. Коробейнікової, В.Р. Лемещук, Н.В. Шульгач. - К. : Арій, 2017. - 160 с. (Читаю англійською (AdvancedLevel))

Інформаційні ресурси в Інтернет

1. http://www.bbc.co.uk/learningenglish/english/features/pronunciation/tims-pronunciationworkshop-ep-6

2. https://www.buzzle.com/topics

3. https://www.bbc.co.uk/podcasts 